\title{
The Likelihood of Fraudulent Financial Reporting: The New Implementation of Malaysian Code of Corporate Governance (MCCG)
} 2017

\author{
Siti Fadilah Bt Mat Zin ${ }^{1}$, Marziana Madah Marzuki ${ }^{1} \&$ Nik Kamaruzaman Hj. Abdulatiff ${ }^{1}$ \\ ${ }^{1}$ Faculty of Accountancy, Universiti Teknologi Mara, Cawangan Kelantan, Malaysia \\ Correspondence: Marziana Madah Marzuki, Faculty of Accountancy, Universiti Teknologi Mara, Cawangan \\ Kelantan, Malaysia. E-mail: marzianamadah@uitm.edu.my
}

Received: March 16, 2020

Accepted: April 30, 2020

Online Published: June 29, 2020

doi:10.5430/ijfr.v11n3p84

URL: https://doi.org/10.5430/ijfr.v11n3p84

\begin{abstract}
On 26 April 2017 Securities Commission Malaysia has released new Malaysian Code of Corporate Governance (MCCG 2017) replacing MCCG 2012 with several changes and recommendations to enhance corporate's accountability, transparency and sustainability. Therefore, the objective of this study is to compare the degree of compliance of this new MCCG 2017 among healthy companies and likelihood of fraudulent financial reporting companies using PN17 companies as a proxy. This study used content analysis of MCCG 2017 and disclosures provided in the annual report of the companies and analyzed it using descriptive statistics. We find that the degree of compliance even among healthy companies in Malaysia in terms of board diversity and board remuneration is still insufficient, and some of the companies are still reluctant to comply. This study provides initial evidence on the effect of new amendment of MCCG 2017 on the likelihood of fraudulent financial reporting in Malaysia.
\end{abstract}

Keywords: MCCG 2017, corporate governance, women, remuneration, PN17

\section{Introduction}

The fraudulent financial reporting has been a controversial topic worldwide. This is because of the enormous losses incurred by the companies or organizations after the crime was revealed. According to the 2018 Global study on occupational fraud and abuse, the fraudulent financial reporting was reported as the first rank of huge losses occurred, which was USD800,000 as compared to misappropriation of assets and corruption, which are USD114,000 and USD250,000, respectively (ACFE, 2018). The fraudulent financial reporting opened the world's eyes through the collapse of big companies such as Enron Corporation, Worldcom, Parmalat in the early 2000s. The fraudulent financial reporting, also known as white-collar crime, came in many reasons such as the possession materials, money, power, and privilege (Scholtz, 2013).

The collapse of big companies due to corporate scandals such as Enron, Worldcom, Parmalat is due to the weak corporate governance practices in the companies (Grove \& Cook, 2007; Costa, 2017). Malaysia also faced the same cases as US, UK, Italy such as Transmile Group which fall into bankruptcy in 2007 resulted loss in market capitalization of 1.2 billion in 2007, Megan Media which the company incurred 1.27 billion and negative cash flow of 897 million (Hamid et al., 2013), Port Klang Free Zone (PKFZ) and the recent corporate scandal involved Federal Land Development Authority (FELDA) where RM1 billion being transferred through dubious means in 2015 (Ismail, Nawani, Smith, \& Puteh Salin, 2018). Malaysia once again hit by the most controversial corporate scandal known as 1 Malaysia Development Berhad (1MDB) where RM4.5 billion worth of money was laundered via series of complex transactions and fraudulent shell companies with bank accounts located in Singapore, Switzerland, Luxembourg and the United State (Ismail et al., 2018)

To combat the fraudulent financial reporting, Malaysia, Malaysia has introduced the Malaysia Code of Corporate Governance (MCCG) in the early 2000s. The MCCG has been revised in 2007 and 2012 to ensure that it remains and aligned with globally recognized best practices and standards. The MCCG once again being revised in 2017 to promote greater internalization of corporate governance culture Nevertheless, fewer studies have been done to investigate the effect of the current amendment towards the practice of the companies. Mastura and Marimuthu (2019) examine the comparison of MCCG 2012 and MCCG 2017 on the board tenure and board independence 
among the oil and gas companies in Malaysia. Ganesan and Mushtaq (2018) examine the relationship between corporate governance mechanism in MCCG 2017 and business performance of the manufacturing companies in Malaysia and find that multiple directorships and business performance have a significant negative relationship while no relationship between gender diversity on business performance.

To date no studies have been done on the MCCG 2017 and the likelihood of fraudulent financial reporting. Therefore, the objective of this study is to compare the degree of compliance of new changes of MCCG 2017 related to boards among the healthy and PN17 companies. The new MCCG 2017 recommends the board diversity by at least 30\% of women directors on board. In terms of board remuneration, the MCCG 2017 proposed the proper disclosure of board remuneration in the annual report.

Using content analysis of MCCG 2017 and annual report of companies, this study finds that level of compliance for the presence of $30 \%$ of women on board is still not impressive even for healthy companies. Despite of that, the result provide evidence that healthy companies are more comply with the board diversity as compared to PN17 companies. For board remuneration disclosures, most of the companies either PN17 or healthy companies comply with the disclosure of the board of directors' remuneration. Nevertheless, most of the companies do not disclose the top five senior management, especially for healthy companies, and none of both type companies disclose the individual senior management remuneration. Our study contributes to provide initial evidence on the effect of MCCG 2017 and likelihood of fraudulent financial reporting in Malaysia.

The paper is organized as follows. In Section 2, we present the development of Malaysia Code of Corporate Governance. Then in Section 3 we present literatures on fraudulent financial reporting, women on board and directors' remuneration. In Section 4 we discuss methodology and lastly, in Section 5 we present our findings. We conclude the implications of our research in Section 6.

\section{Development of Malaysia Code of Corporate Governance (MCCG)}

The Corporate Governance (CG) is defined as the process and structure used to direct and manage the business and affairs of the company towards promoting business prosperity and corporate accountability with the ultimate objective of realizing long-term shareholder value while taking into account the interest of other stakeholders. Due to the Asian financial crisis in 1997, Malaysia, for the first time, has introduced MCCG 2000 to combat the fraudulent financial reporting in which covering the principles and best practices of good governance and describing optimal corporate governance structures and internal processes. All companies in Malaysia were required to comply with the code of practice to strengthen the quality of Malaysia Financial Reporting and Capital Market. The MCCG 2000 emphasized on (i) the duties, obligation, rights, and liabilities of directors, company officers and controlling shareholders, (ii) to maintain the adequacy of disclosure of conflicts of interests, (iii) enhancing the quality of general meeting, (iv) efficacy in the provision of shareholder remedies and (v) the enforcement of good corporate governance. The MCCG was revised in 2007 to strengthen the boards of directors and the audit committee by ensuring the responsibility of the board of directors and audit committee are carried out effectively. Later, the new revision of MCCG has been made in 2012, known as MCCG 2012. The amended MCCG 2012 focuses on clarifying the role of the board in providing leadership, enhancing board effectiveness through strengthening its composition and reinforcing independence. The MCCG 2012 also encourages companies to place corporate disclosure policy that embodies principles of good disclosure and to make public their commitment in respect of shareholder rights.

On 26 April 2017, the MCCG once again make revisions as MCCG 2017. The new MCCG 2017 introduced substantial changes and recommendations with a view of raising the standard of CG in Malaysia. Previously, MCCG is only applicable to large Companies, which are the Companies Listed in Top 100 FTSE Bursa Malaysia. The new MCCG 2017 now encourage non-listed entities such as state-owned enterprise, SMEs, and licensed intermediaries to adopt the code to enhance accountability, transparency, and sustainability. Among the amendment of MCCG 2017 on board matters including strengthening the independence of the board in which the companies must have at least half of the independent director and for large companies, there must be majority of independent directors. In addition to that, the new MCCG 2017 proposed two important new changes on board matters which are (i) the presence of women directors on board must be at least $30 \%$ and (iii) the disclosure detail on named basis of the remuneration paid to directors. Below are the details of the changes proposed by the MCCG 2017:

Practice 4.5: The large companies are required to have 30\% of women directors

Practice 7.1: There is detailed disclosure on the named basis for the remuneration of individual directors. The remuneration breakdown of individual directors includes fees, salary, bonus, benefits-in-kind and other emoluments. 
Practice 7.2: The board discloses on named basis the top five senior management's remuneration component including salary, bonus, benefit-in-kind and other emoluments in bands of RM50,000

Practice 7.3: Companies are encouraged to fully disclose the detailed remuneration of each member of senior management on a named basis

The new amendments on women directors and board remuneration disclosures are seen as significant in detecting the likelihood of fraudulent financial reporting as the women have a different perspective than men (Ganesan \& Mushtaq, 2018). Besides, the remuneration package for the board will influence the action to be taken in order to receive high compensation for the year (Johnson \& Ryan, 2003). Nevertheless, the evidence on the practice of these two amendments are scarce. Thus, our study will focus on the implementation of these changes among PN17 and healthy companies in Malaysia.

\section{Literature Review}

\subsection{Fraudulent Financial Reporting}

Fraudulent financial reporting is described as the intentional act by one or more people in an organization to achieve their personal goal. In other words, the fraudulent financial reporting generally defined as the intended deceives or misrepresents in one way to others. There are five basics of financial statement fraud, which are fictitious sales, improper expenses recognition, incorrect asset valuation, hidden liabilities, and unsuitable disclosures. According to Manurung and Hadian (2013), fraud also can be seen as misrepresentation, storage or negligence of the truth for the purpose of manipulating financial reporting and it may cause harm to the companies and organizations. It resulted in huge losses not only for the organization itself but also affected the other stakeholders including shareholders, employees, creditors, etc.

Fraudulent financial reporting resulting from poor corporate governance has been studied by many researchers. The study by Chariri and Mahesarani (2017) on Indonesian Stock Exchange finds that corporate governance factors such as the proportion of independent board, managerial ownership, audit committee meetings, and interaction of the external auditors quality and audit committee meeting influencing the financial statement fraud. Similarly, the study by Utomo, Machmuddah, and Pamungkas (2019) in Indonesia Stock Exchange found that the increasing number of auditor switching have a high tendency of fraudulent financial reporting. In'airat (2015) in his study in Saudi Arabia finds that the Internal Audit function plays a significant role in minimizing the level of fraud in companies. In Malaysia, a study by Wan Mohd Razali and Arshad (2014) finds that the effective board members are the basis to enhance the overall corporate governance effectiveness.

\subsection{Women on Board}

Typically, the board of directors conquered by men which also known as the "boys club". The presence of women on the corporate board had been an important debate among scholars around the globe. This is because the specific characteristics of women, such as risk aversion, have different core values and ethics (Allemand et al., 2017). Men and women have different core values. Women found to be risk-averse and take less risk as compared to men (Croson \& Gneezy, 2009). The risk aversion and risk-taking may influence economic performance as well as the quality of financial reporting itself (Allemand et al., 2017).

Some countries have passed some legislation by establishing a gender quota system by reserving seat for women on the board of directors. For example, in 2011, a new law adopted in France called Loi Cope Zimmermann was adopted, which required the public companies to increase to $40 \%$ of the percentage of women on the board of directors (Allemand et al., 2017). The other countries, such as Norway and Spain, also required $40 \%$ female directors since 2008 and 2015 respectively. In the study of $\mathrm{Na}$ and Hong (2017) on the CEO gender and earning management finds that the male CEO are likely to use aggressive discretionary accruals in order to report small positive earnings whereas the female CEO's are not likely to engage in aggressive earning managements. The study conducted in Amman Stock Exchange Jordan by Makhlouf, Al-sufy, and Almubaideen (2018) on board diversity and accounting conservatism finds that board diversity has a positive and significantly related to accounting conservatism. Based on the result of the study, the Makhlouf et al. (2018) suggests that board diversity is necessary to take in an organization as it may influence the director's behaviour when they are facing any problems. Ginesti, Drago, Macchioni, and Sannino (2018) in their study on whether female board participation affects annual report transparency in terms of readability, find that female board participation has a positive relationship with annual report transparency. They find that the increase in board diversity contributes to the reinforcement of governance mechanism, thus leading to a general improvement in the corporate reporting practice. Although many literatures supported the board diversity, the study by Firoozi, Magnan, and Fortin (2016) on the impact of board diversity as the key aspect of decision 
making process and financial reporting quality finds the different result from previous literatures. The study finds that the presence of women on board do not related to financial reporting quality. He stated that the gender diversity which are the presence of women director may not adequately capture the dynamic board decision making.

\subsection{Board Remuneration}

Board compensation can be one of the factors that contribute to fraudulent financial reporting (Zam, Pok, \& Ahmed, 2014). Typically, the directors are struggled to maintain their performance to retain their compensation. The board compensation usually being paid in terms of cash, stock, and stock option (Kim, Roden, \& Cox, 2013). Due to achieving the high compensation, the independence of the board might be compromised and this may lead to the probability of fraud. According to Scholtz (2013), the CEO faced a dilemma as they are required to set an increasingly higher financial targets to receive a bonus or share option. Therefore, they will tend to manipulate the financial statement to reach their expected target.

Various studies have been done to investigate the effect of board remuneration on fraudulent financial reporting. Kim et al., (2013) finds that the type of compensation has a significant impact on the likelihood of fraud. This is because the directors are intended to manipulate earnings and hide the poor performance of the company to obtain high stock prices. This study clearly shows that the use of options compromises the director independence and impair their ability to provide oversight. Archambeault, Dezoort, and Hermanson (2008) in their study finds positive relationship between audit committee short-term and long-term stock option grants and accounting restatements. They argued that when the companies issue short-term options to audit committee members, the probability of the quality of oversight is reduced as the audit committee member's focus on the short-term performance. Johnson and Ryan (2003) in his study of executive compensation and corporate fraud finds that the executives who commit fraud exercise a larger fraction of their stock option resulted greater total compensation. The study suggest that the fraud occurred during the slowdown of earnings growth. In addition, the study conclude that the stock return is relatively during the fraud period and the executives are more likely to commit fraud during the industry downturns. In contrast, Zam et al. (2014) finds no evidence of compensation structure of both scandal firm and non-scandal. The study conclude that the compensation structure does not contribute to fraud occurrence in Malaysia.

Despite of the mixed results on the effect of women on boards and board remuneration, there are less evidences on the extent of companies practise the new changes of MCCG 2017. In addition, MCCG 2017 provides an interesting change as it shifts from the 'comply or explain' method in the 2012 code to a 'apply or explain an alternative'. Therefore, this study tries to answer research question on how far the companies comply with the new changes of MCCG 2017 focusing on changes related to boards which are the requirement to have $30 \%$ women on board and to disclose board remuneration. Next, we try to answer research question is there any difference between healthy companies and PN17 companies on the compliance in order to provide initial evidence on the effect of new changes of MCCG 2017 on probability of fraudulent financial reporting.

\section{Methodology}

The sample of data of this study consists of 26 listed companies which consist of 13 financial distress companies that are categorized as PN17 companies. The PN17 companies then match with 13 healthy companies with the same industry and similar total assets. We use PN17 companies as proxy for probability of fraudulent financial reporting as the financial distress companies are more likely to manipulate their financial statement to position themselves better, thus may lead the companies into fraudulent financial reporting (Arshad, 2015).

The data collection was a year only which is 2018 which is a year after the revision of MCCG 2017. The reason for selecting only one year as the data because the purpose of this study is to see the implication of the new amendment of MCCG 2017. Therefore, the companies were selected as pre-evidence upon the revision of the new MCCG 2017. The information obtained from the annual report is used for the purpose of analysing whether the companies are complied or implemented the current changes of MCCG 2017. Even though the total number of PN17 companies are more than 13 companies in 2018, this study unable to collect all the data from the PN17 companies as no annual report issued in the year 2018. Thus, the companies who did not issue an annual report in 2018 is excluded from the sample test.

For the purpose of this study, we use content analysis of MCCG 2017 and disclosures provided in the annual report of the companies. Based on the requirement of MCCG 2017, we check the disclosures of annual report of each sample to investigate the extent of companies complied with the new requirement. The degree of compliance is analyzed using frequencies of disclosures and any departures from the compliance are explained in the discussion of findings. 


\section{Findings and Discussion}

\subsection{Women on Board}

Table 1 above shows the result of the level of compliance to have at least $30 \%$ of women on board. Based on the evidence, it shows that only two companies (15\%) of the total sample of PN17 Companies complied with the rules of $30 \%$ of women on board. The balance of $23 \%$ and $62 \%$ represent the compliance less than $(<) 30 \%$ and non-compliance, respectively. The result of PN17 Companies indicates that most of the PN17 companies yet to comply with the new MCCG 2017. The reason for non-compliance including the company's in the opinion that the board gender diversity policy is not necessary to adopt in the company as the company is committed to providing fair and equal opportunities and nurturing within the group of companies. Besides, the selection of the directors is primarily based on the effective blend of competencies, skill, extensive experience, and knowledge in the specific areas. Thus, the companies give to that characteristic rather than gender diversity. Some companies which do not have women directors on the board, such as Berjaya Media Berhad, Comintel Berhad, and Sumantec Resources Berhad even though they did not comply with the recommendation by MCCG, the board would endeavor to meet the requirement by MCCG 2017 and will recommend the suitable female candidate for gender diversity. The company, such as Eka Noodles stress that they would comply with the board gender diversity after they lift the PN17 status.

In contrast, the result of healthy companies shows that $38 \%$ of the total companies have at least $30 \%$ women directors. Another 38\% companies do not comply with the requirement. Meanwhile, 23\% of the total companies are in the middle of meeting the requirement. Based on the result presented in Table 1, it shows that the healthy companies are more compliant as compared to the PN17, in which a total of $61 \%$ of healthy companies are full comply and in the middle of complying it.

Table 1. Disclosures of $30 \%$ women on board

\begin{tabular}{rcccc}
\hline $\begin{array}{c}\text { Level of } \\
\text { Compliance }\end{array}$ & PN 17 Companies & $\begin{array}{c}\text { Frequencies } \\
(\mathbf{\%})\end{array}$ & $\begin{array}{c}\text { Healthy } \\
\text { Companies }\end{array}$ & $\begin{array}{c}\text { Frequencies } \\
(\boldsymbol{\%})\end{array}$ \\
\hline $30 \%$ Applied & 2 & $15 \%$ & 5 & $38 \%$ \\
\hline $\begin{array}{c}<30 \% \\
\text { Applied }\end{array}$ & 3 & $23 \%$ & 3 & $23 \%$ \\
\hline Departure & 8 & $62 \%$ & 5 & $38 \%$ \\
\hline Total & $\mathbf{1 3}$ & $\mathbf{1 0 0 \%}$ & $\mathbf{1 3}$ & $\mathbf{1 0 0 \%}$ \\
\hline
\end{tabular}

Overall, the result shows that the level of compliance is still not impressing even for healthy companies. About $38 \%$ of the healthy companies are still not complying with the new regulation. The percentage of companies that have less than $30 \%$ directors is the same for healthy and PN17 companies which is $23 \%$. The result shows that much effort still needs to be done to promote the importance of having women on board among the companies. Some of the companies argued that even though they do not comply with this regulation, they still provide fair and equal opportunities and nurturing within the group of companies. This statement is too general and how far they provide fair and equal opportunities is not well disclosed. Some of the companies stated that they are in the middle of the process of adopting the new amendment. Nevertheless, no disclosures are provided on what has been done so far as an effort to adopt it. Despite of that, the result provides initial evidence that healthy companies have more women on board as compared to PN17 companies providing possibilities of associating women on board and the likelihood of fraudulent financial reporting.

\subsection{Board Remuneration}

Table 2 shows that the result of the detailed disclosure on the named basis for the remuneration of individual directors. From the result, 92\% of PN17 Companies and 100\% of healthy companies complied with the requirement of MCCG 2017 to disclose individual board remuneration. 
Table 2. Disclosures of individual board's remuneration

\begin{tabular}{ccccc}
\hline $\begin{array}{c}\text { Level of } \\
\text { Compliance }\end{array}$ & $\begin{array}{c}\text { PN 17 } \\
\text { Companies }\end{array}$ & $\begin{array}{c}\text { Frequencies } \\
(\boldsymbol{\%})\end{array}$ & $\begin{array}{c}\text { Healthy } \\
\text { Companies }\end{array}$ & $\begin{array}{c}\text { Frequencies } \\
(\boldsymbol{\%})\end{array}$ \\
\hline Applied & 12 & $92 \%$ & 13 & $100 \%$ \\
\hline Non-applied & 1 & $8 \%$ & 0 & $0 \%$ \\
\hline Total & $\mathbf{1 3}$ & $\mathbf{1 0 0 \%}$ & $\mathbf{1 3}$ & $\mathbf{1 0 0 \%}$ \\
\hline
\end{tabular}

Table 3 below shows the result of the basis disclosure of the top five senior management's remuneration. The top five senior managements play an important role in the companies as they are the main key decision-makers of the companies. Based on the sample selected, $85 \%$ of PN17 companies complied with the recommendation, whereas $15 \%$ non-comply with the MCCG 2017. The result contradicts with the healthy companies where only $46 \%$ comply with the recommendation while $54 \%$ otherwise. The reason for non-compliance with this practice, including:

i. The disclosure is the sensitive nature of such information and fierce competition for specific industries.

ii. The five key senior management remuneration is similar to the other management employees of the company.

iii. The company believes that the disclosure would not be in the best interest of the company as it provides competitiveness for the specific industries.

Despite of the incompliance, most of the companies stated that the board would continuously review and continuously undertake a robust internal process to ensure that the remuneration of senior management is competitive and fair.

Table 3. Disclosures of top five senior management's remuneration

\begin{tabular}{ccccc}
\hline $\begin{array}{l}\text { Level of } \\
\text { Compliance }\end{array}$ & $\begin{array}{c}\text { PN 17 } \\
\text { Companies }\end{array}$ & $\begin{array}{c}\text { Frequencies } \\
(\boldsymbol{\%})\end{array}$ & $\begin{array}{c}\text { Healthy } \\
\text { Companies }\end{array}$ & $\begin{array}{c}\text { Frequencies } \\
(\boldsymbol{\%})\end{array}$ \\
\hline Applied & 11 & $85 \%$ & 6 & $46 \%$ \\
\hline Non-applied & 2 & $15 \%$ & 7 & $54 \%$ \\
\hline Total & $\mathbf{1 3}$ & $\mathbf{1 0 0 \%}$ & $\mathbf{1 3}$ & $\mathbf{1 0 0 \%}$ \\
\hline
\end{tabular}

Table 4 shows the result of the detailed disclosure remuneration of each member of senior management on a named basis. Based on the sample selected, none of the PN17 companies or healthy companies adopted the recommendation. This new requirement of MCCG 2017shows that the companies are not in interest in disclosing all the details of senior management in an annual report. The companies may hold opinion that disclosing the details of remuneration for each of senior management is not an important requirement as disclosing the remuneration of top five senior management is already adequate in portraying the accountability and transparency of companies.

Table 4. Disclosure of the detailed remuneration of each member of senior management

\begin{tabular}{ccccc}
\hline $\begin{array}{l}\text { Level of } \\
\text { Compliance }\end{array}$ & PN 17 Companies & $\begin{array}{c}\text { Frequencies } \\
(\mathbf{\%})\end{array}$ & $\begin{array}{c}\text { Healthy } \\
\text { Companies }\end{array}$ & $\begin{array}{c}\text { Frequencies } \\
(\mathbf{\%})\end{array}$ \\
\hline Applied & 0 & $0 \%$ & 0 & $0 \%$ \\
\hline Non-applied & 13 & $100 \%$ & 13 & $100 \%$ \\
\hline Total & $\mathbf{1 3}$ & $\mathbf{1 0 0 \%}$ & $\mathbf{1 3}$ & $\mathbf{1 0 0 \%}$ \\
\hline
\end{tabular}

Overall, most of the companies comply with the requirement of MCCG 2017 to disclose board remuneration. Nevertheless, the results of the new requirement of MCCG 2017 for the disclosure of senior management's is still far from compliance even for healthy companies. The result indicates that many companies are reluctant to disclose the board remuneration due to fear of competitiveness. It shows that remuneration is seen not as a tool for measuring performance but rather as a competitive tool. 


\section{Conclusion}

This study aims to investigate the degree of compliance of new changes of MCCG 2017 relating to board of directors and to compare the practice between PN17 and healthy companies. We use PN17 companies as a proxy for likelihood of fraudulent financial reporting as distress companies have tendency to manipulate their financial reporting to show good performance and thus provide initial evidence on the relationship between likelihood of fraudulent financial reporting and implementation of new code of MCCG 2017. The result indicates that the level of compliance for the presence of $30 \%$ of women on board is still not impressive even for healthy companies where only 15\% compliance for PN17 companies and 38\% compliance for healthy companies. Nevertheless, the result provide evidence that healthy companies are more comply with the new changes of MCCG 2017 as compared to PN17 companies. For board remuneration disclosures, most of the companies either PN17 or healthy companies comply with the disclosure of the board of directors' remuneration. Nevertheless, most of the companies do not disclose the top five senior management, especially for healthy companies, and none of both type companies disclose the individual senior management remuneration.

The result indicates that much effort needs to be done by the regulators to enforce the compliance of the companies with the new regulation. Most of the companies who do not hire 30\% women on board suggest that gender diversity policy is not necessary to be adopted in the company as the company is already committed to providing fair and equal opportunities and nurturing within the group of companies based on the effective blend of competencies, skill, extensive experience, and knowledge in the specific areas. It seems that the companies still do not appreciate of having women on board towards their companies. Thus, the regulators in this country need to create awareness on the significance of having women on board to enhance the level of compliance of new MCCG 2017.

In addition, the regulators should expose the awareness of remuneration disclosure that may influence the directors' behaviour and level of transparency in mitigating the corporate scandal. Most of the companies disclose the remuneration of board of directors but reluctant to disclose senior managements' remuneration in details. Among the reasons give by them for not disclosing are fear of competitiveness among the industries and the information is sensitive in nature. Thus, discussions need to be held between the regulators and these companies in order to solve the problem. Further investigation needs to be done by the regulators to ensure that the incompliance is not because of excess of managers' compensation, or fear of media attention as suggested by Robinson, Xue and Yu (2011).

However, some limitations should be highlighted in the study. Firstly, the data selected was only one year, which is the annual report 2018. As the sample of the study consists of 13 PN17 companies and 13 healthy companies, then this cannot be proved by complex statistical evidence as the number is minimal. Therefore, the result provided in this study only the pre-evidence of compliance of MCCG 2017. Future research may extend the sample number of the selected companies to include several years so that the result might represent the overall companies in Malaysia.

\section{Acknowledgements}

The authors wish to express their gratitude to the Ministry of Higher Education for funding this research project through the Grant Scheme (600-IRMI/FRGS 5/3 (070/2017) and University Teknologi MARA (UiTM) Kelantan for the administrative support.

\section{References}

Allemand, I., Andre, P., Schatt, A., \& Lausanne, H. E. C. (2017). Women Involved In The Financial Reporting Process and Financial Reporting Quality. Retrieved from file://C:/Users/ASUS/Downloads/SSRN-id3009375.pdf

Archambeault, D. S., Dezoort, F. T., \& Hermanson, D. R. (2008). Audit Committee Incentive Compensation And Accounting Restatements. Contemporary Accounting Research, 25(4), 965-992.

Arshad, R., Iqbal, S. M., \& Omar, N. (2015). Prediction of business failure and fraudulent financial reporting: Evidence from Malaysia. Indian Journal of Corporate Governance, 8(1), 34-53.

Association of Certified Fraud Examiners (ACFE). (2018). Report to The Nations: 2018 Global Study On Occupational Fraud And Abuse 4 Retrieved https://s3-us-west-2.amazonaws.com/acfepublic/2018-report-to-the-nations.pdf

Chariri, A., \& Mahesarani, D. S. (2017). Corporate Governance And Financial Statement Frauds : Evidence From Indonesia Corporate Governance And Financial Statement Frauds. Retrieved from http://eprints.undip.ac.id/66646/1/21_Proceeding_ICEEBA.pdf 
Costa, A. P. P. Da. (2017). Corporate Governance And Fraud: Evolution And Considerations. Corporate Governance and Strategic Decision Making, 23.

Croson, R., \& Gneezy, U. (2009). Gender differences in preferences. Journal of Economic literature, 47(2), 448-74.

Firoozi, M., Magnan, M., \& Fortin, S. (2016). Board Diversity and Financial Reporting Quality. Retrieved from http://www.icd.ca/getmedia

Ganesan, Y., Kanthan, G., Mushtaq, M., \& Yeap, J. A. (2018). The Moderating Role of Internal Audit Function on the Relationship Between Board of Director Characteristics and Business Performance in Malaysia. Global Business and Management Research, 10(1), 356-378.

Ginesti, G., Drago, C., Macchioni, R., \& Sannino, G. (2018). Female board participation and annual report readability in firms with boardroom connections. Gender in Management: An International Journal, 33(4), 296-314.

Grove, H., \& Cook, T. (2007). Fraudulent Financial Reporting Detection: Corporate Governance Red Flags. Corporate Ownership and Control, 4(4), 254-261.

Hamid, F. Z. A., Shafie, R., Othman, Z., Hussin, W. N. W., \& Fadzil, F. H. (2013). Cooking the Books: The Case of Malaysian Listed Companies, International Journal of Business and Social Science, 4(13), 179-186.

In'airat, M. (2015). The Role Of Corporate Governance In Fraud Reduction - A Perception Study In The Saudi Arabia Business Environment Mohammad In' Airat Ibn Rushd College For Management Sciences. Journal Accouting And Finance, 15(2), 119-128.

Johnson, S. A., Ryan, H. E. Jr., \& Tian, Y. S. (2005). Executive Compensation and Corporate Fraud. Working paper Texas A\&M University. Retrieved from https://archive.nyu.edu/bitstream/2451/27548/2/SSRN-id813088.pdf

Kim, J. Y., Roden, D. M., \& Cox, S. R. (2013). The composition and compensation of the board of directors as predictors of corporate fraud. Accounting and Finance Research, 2(3), 142-154.

Makhlouf, M. H., Al-Sufy, F. J., \& Almubaideen, H. (2018). Board diversity and accounting conservatism: Evidence from Jordan. International Business Research, 11(7), 130-141.

Manurung, D. T., \& Hadian, N. (2013). Detection fraud of financial statement with fraud triangle. Proceedings of 23rd International Business Research Conference, World Business Institute, 18-20 November 2013, Marriott Hotel Melbourne, Australia.

Mastura, D., \& Marimuthu, M. (2019). Comparison Of Mccg 2012 And Mccg 2017 : Board Tenure And Board Independence Across The Malaysian Oil And Gas Plcs. Business Management And Strategy, 10(2), 82-96.

Na, K., \& Hong, J. (2017). CEO Gender and Earnings Management. Journal of Applied Business Research (JABR), 33(2), 297-308.

Robinson, J. R., Xue, Y., \& Yu, Y. (2011). Determinants of disclosure noncompliance and the effect of the SEC review: Evidence from the 2006 mandated compensation disclosure regulations. The Accounting Review, 86(4), 1415-1444.

Salin, A. S. A. P., Ismail, Z., Smith, M., \& Nawawi, A. (2019). The influence of a board's ethical commitment on corporate governance in enhancing a company's corporate performance. Journal of Financial Crime, 26(2), 496-518.

Scholtz, H. E. (2013). Share Options As Part Of Executive Remuneration : Aligning The Interests Of Stakeholders. Southern African Business Review, 13(2), 58-87.

Utomo, S. T. D., Machmuddah, Z., \& Pamungkas, I. D. (2019). The Effect Of Auditor Switching And Managerial Ownership On Fraudulent Financial Statement. Wseas Transactions on Business and Economics, 16, 306-315.

Wan Mohd Razali, W. A. A., \& Arshad, R. (2014). Disclosure Of Corporate Governance Structure And The Likelihood Of Fraudulent Financial Reporting. Procedia - Social And Behavioral Sciences, 145, 243-253.

Zam, Z. M., Pok, W. C., \& Ahmed, A. D. (2014). Factors of fraud occurrence and corporate governance structures: Evidence from emerging market Malaysia. Corporate Ownership and Control, 11(3), 135-153. 